\title{
Technology-Based Projects in Medical English
}

\author{
Anişoara POP \\ University of Medicine and Pharmacy of Târgu Mureş \\ pop.anisoara@umftgm.ro \\ Raluca CRIŞAN \\ Babeş-Bolyai University of Cluj-Napoca \\ raluca_crisan_86@yahoo.com
}

\begin{abstract}
The paper presents empirical results of applying asynchronous writing and speaking tools in Medical English learning (ME). Class-size Voice-Thread and Blogger-based non-mandatory projects were conducted with general and dental medicine students in two consecutive years for one semester each, with significantly improved outcomes in terms of extension of the writing and speaking time in the target language, motivation and engagement levels as well as confidence and awareness of one's competence.
\end{abstract}

Keywords: technology, Medical English, ESP, VoiceThread, blog

\section{Emerging technologies in $\mathrm{ME}$}

Emerging technologies have been reshaping language teaching and learning by making students more active, engaged, and motivated learners (Lerner 2009) while promoting autonomy, reflection, and collaboration. Moreover, technology-based projects apply the novel concept of minimally-invasive education (Mitra 2011), the pedagogical method that uses "the learning environment to generate an adequate level of motivation to induce learning. Students working autonomously or from peers are more likely to take more responsibility for their own learning in the future".

Within the context of internationalization of services and training in the medical field, pre-service medical students face the challenge of employing English in their life-long learning and future professional development through conference presentation, article publication, international team building for evidence-based decision-making, as well as patient-doctor communication. Consequently, communicative competence becomes a key issue in teaching and learning English for Medical Purposes (EMP). 
This paper is a survey of technology-based projects carried out in two successive years with ME students of the University of Medicine and Pharmacy of Tîrgu-Mureş, Romania, within the framework of task-based learning. It reflects on harnessing emerging technologies (i.e. speaking and writing tools) and allowing partial control (McFarland 2009) to course participants, resulting in more active and communicative ME language learning experiences.

\section{Added value of technology in ME writing and speaking}

The general Medical English teaching format is not different from that of other ESPs, and is based on teaching large mixed ability groups for a total of less than 100 hours (structured on two modules and 4 semesters, i.e. two hours/week) in the first two years of study as part of the core curriculum of complementary subjects. Physical restraints (the amount of time and formation of all skills, mixed entry levels of competence) are seconded by the generally acknowledged increased difficulty of the first years in medical higher education when the students' basic motivation is to acquire field knowledge to the detriment of English language learning and awareness.

In terms of basic competences, conference presentations and article writing make writing and speaking key ME productive skills that encompass the two extremes of formality: distance (highest formality in writing) versus informality (closeness in speaking), and premeditated production (access to resources is possible in the case of writing) versus spontaneous production (real-time, in the case of speaking).

Speaking is involved in giving feedback to patient stories in the process of patient management from history taking to informal bed-side or professional case presentations. However, class-speaking is fraught with limitations due to large groups and mixed ability in accuracy-fluency. On the other hand, teaching ME writing presents certain difficulties pertaining to amount (restricted time devoted to ESP within the medical curriculum), commitment (involves additional time investment for reflection, which makes writing less desirable for class activities), and motivation (writing activities are de-motivating and boring as they involve planning, drafting, revising). Writing assessment has also evolved from tests for composition skills to portfolio-based writing, the latter offering a more faithful picture of the students' progress and development (Hirvela 2005).

The next section of the paper will detail the way in which technology was used to encourage spoken and written production extension while responding to future doctors' professional communication demands. More specifically, it will explore the benefits of customizing asynchronous blog writing and VoiceThread speaking for Medical English. We hypothesized that emerging technology- 
enhanced projects will optimize communication towards more active and autonomous ME production, likely to prepare students for career advancement, attendance at conferences, academic and work collaboration across borders and internalization of workplaces.

\section{Project presentation}

\subsection{Method}

The study is a retrospective survey that investigates technology-based asynchronous writing and speaking with Blogger (B-writing) and VoiceThread (VT-speaking) respectively, on the basis of:

- text analysis for assessment of time, volume, and quality of production (comment monitoring for VT-speaking plus individual feedback for B-writing);

- reflection on action of both students and trainer for both projects (Yang, 2009);

- end-of-project questionnaire-based oral interview for evaluation of students' motivation and attitude (VT-speaking).

Technology-based asynchronous activities were:

- non-mandatory, complementary, learning and communication-oriented;

- basically task-based: i.e. the primary objective was communicative rather than linguistic; students were confronted with real, field-specific tasks (e.g. advise a patient on oral health and treatment plan - B-writing; "How can the state health system be improved" - VT-speaking); focus on language was secondary to the communicative task.

Subjects were second-year students in Dental Medicine ( $N=25$ participants out of 62) for the B-writing, and second-year General Medicine students for the VT-speaking project ( $\mathrm{N}=80$ participants).

Learner profiles. Participants in the two projects had A2-B2 levels in terms of ESP language proficiency, and apart from accessing materials on the class wiki or the university e-learning platform, students had no previous exposure to technology-based projects in any other mainstream subject or language learning.

Purpose:

- active and communicative ME speaking and writing (Murray, 2007);

- activation of online reading and listening;

- increased motivation and engagement in autonomous ME practice;

-building additional extra-linguistic academic skills: searching for information, synthesizing and developing arguments, remixing and rephrasing information. 


\subsection{Voice Thread - Asynchronous speaking project}

Voice Thread (Educause, 2009) is an interactive, multimedia tool that enables conversation around various types of media: images, videos, PP, which can be adapted to different proficiency levels while offering students the opportunity to share and listen to their voices.

However, in terms of models, there is a gap of evidence-based successful application of VT in higher education (Bart 2011, Brunvand 2011, Gillis 2012), let alone ME learning (Aponte 2010). The starting premise of our ME-VT application was that extension of speaking through meaningful, task-based asynchronous activities will optimize speaking and contribute to the formation of public speaking confidence and competence, essential for the medical profession.

The group of 80 second-year students was involved in the class-sized VT-based speaking project in the months of February-June 2013 (https://voicethread. $\mathrm{com} /$ share/4370164/). Speaking with VT, functioned as a springboard for more engaging, relevant speaking activities, which were subsequently used as a formative assessment tool (Pop 2013), on the following topics: basic qualities for a good doctor, how to improve the state health system versus private practices in Romania, facets of medical specialities, lessons learnt from movies/books on the medical profession - case studies, a hospital experience - reflections on medical life seen from the hospital bed, symptoms of different diseases (guessing game).

Students worked on the speaking skills of debating, exemplifying, arguing, and on sub-skills, i.e.: intonation, stress, weak forms, use of cohesive devices, discourse markers for introducing ideas, developing, explaining, and concluding.

End-of-project oral interview evaluated:

a) students' satisfaction with the VT-speaking project: 70 students $(87.5 \%)$ enjoyed speaking on the proposed topics and found the experience novel and motivating. The rest encountered technical problems in recording (lack of microphone, Internet connection);

b) students' perception of the usefulness of VT-speaking project: $72 \%$ found the speaking useful, $28 \%$ were neuter or did not know;

Outcomes: Using voice tools as a supplement is superior in many ways to realtime speaking and beneficial to pre-service ME students as it is:

- student-centred and democratic: more students had the opportunity to speak rather than only the fluent and confident ones;

- creative: speaking statistics show that 346 asynchronous comments were recorded by $96 \%$ of participating students;

- learning-oriented: prior preparation is possible in asynchronous speaking as well as listening to oneself and others, rehearsing and re-recording, likely to optimize the speaking performance in terms of confidence and quality.

- memorable and transparent. 


\subsection{Asynchronous blog-writing project}

This section will reflect on the project hypothesis, objectives, issues of material design, strong points, and shortcomings of the B-writing project. Blogger was tailored as strategic framework to suit the pedagogical need of communicating in writing for medical purposes and promoting writing quality while offering a space for students to be connected and share content on authentic, field-related topics.

Writing with blogger (http://medicalenglishumf.blogspot.ro) was addressed to $2^{\text {nd }}$-year students in Dental Medicine $(\mathrm{N}=62)$, of which about one third (25 students, $40.3 \%$ ) contributed with single or multiple comments. Activities extended basically for the second semester of the academic year 2013-2014 although the blog posts started during the first semester. Students were initially apprehensive and reluctant to contribute with extra work, as prior informal class discussions and final input demonstrated, although all students admitted the importance of relevant extensive practice for writing enhancement.

The project hypothesis was that: a) extending the writing practice through relevant and engaging topics, b) offering individualized feedback, and c) working in the public space will optimize communicative writing quality in terms of accuracy and fluency while contributing to an enhanced awareness of the students' needs, ability, and confidence in their ME writing.

Therefore, the main objective of our project was to bridge the gap between class $\mathrm{ME}$ learning and real ME communication, through extension of the time spent in the target-language environment and adaptation to the ME communicative needs while developing the students' writing skills: e.g. reflecting, instructing, summarizing (abstract writing), arguing, counselling, giving bad news, empathizing, interviewing in an integrated format with listening, reading, and note-taking.

Material design. With limited field knowledge and lacking task-based peermodels of best practice (unlike in Business English, for instance), the ME teacher faces the challenge of stirring the students' participation and originality, while remaining relevant yet not too content-specific.

The example below will illustrate the customization of content to task-based writing and integration of reading meant to enforce development of patient communication skills, adequate vocabulary recycling, and encouragement of self-expression:

1) Task example:

"One of your patients presents to your dental practice with serious oral problems and he confesses he likes one of the foods/drinks in the slideshow below. Read the presentation on: Foods your dentists avoid, then pick one of the types of foods/drinks your patient exaggerates with, and WRITE A SHORT DIALOGUE of your communication with this patient (5-10 replies), 
advising him/her why he/she should avoid that item and what to do instead. Manifest consideration, politeness for your patient's decisions, but be convincing enough about what is good and bad for his/her teeth in the long run".

This task focused on offering advice to a patient, with consideration of politeness and turn-taking (primary focus). The communicative purpose is evident in the number of comments the task generated (e.g. 70 comments, including teacher replies). The generated comment below shows adequate use of vocabulary with clear argumentation of causes, exemplification, instructions on "how-to" and politeness in advising dental patients:

1) Student comment example:

'Hi Liza, good to see you again. You look so fantastic and I see that you lost some weight as well. What brought you here today? How may I help you?...'

'Hello, Dr. Pancsi! Good to see my best friend as a dentist after two years. I really need your help. You are right, I lost weight by being on a diet and working out hard for a year. However, my teeth are getting discolored and my gum is bleeding and receding. I am worried I might lose my teeth, Dr. Pancsi.'

'Have you been taking any diet pills, Liza?'

'To be honest, yes, as I wanted to get a better result as quick as possible.'

'Oh, Liza, this was a big mistake. You should have asked me for advice before. Even though it may seem like a quick way to trim your waist and lose weight, it can also be a fast track to tooth decay and gum diseases. These pills decrease salivary flow, which causes dry mouth and puts you at risk for tooth decay, cavities, gum disease and comfort. Some of the pills can cause discolored teeth as well. That is the reason why your teeth are getting yellowish, Liza.'

'Please, give me some advice. What am I suppose(d) to do to protect my teeth and gum?'

'First of all, stop taking the pills and start a new diet based on veg(e)table(s) and fruits. Try to eat leafy veg(e)tables, like spinach, as by chewing them, they scrub and clean your teeth. Eat more dairy products, as they are the primary sources of calcium, which is essential for healthy teeth. Calcium stre(n)gthens tooth enamel. For example, cheese is the best dairy product, containing a type of protein which along with calcium, play[s] an important role in stabilizing and repa(i)ring tooth enamel.'

'That's great Pancsi! And what about the color of my teeth? Could you please recommend a natural whitening option?'

'I would [strongly] recommend strawberries! Eat strawberr[ies] as [they] contain malic acid, a natural enamel whitener. The other option would be to crush one strawberry and mix it with baking soda. Spread it on your teeth with a tooth brush and leave it for about 5 minutes and then brush your teeth gently not to harm your gum and teeth. Try to use a soft brush and make circular movements in order to massage your gum to stimulate the circulation of blood in your gum.' 
'Thank you so much, Pancsi for your help. I am grateful for your advice and glad to have you as my best friend. See you soon!' (by B. A.)

A rough statistics of the blog-writing for this post only will amount to an equivalent of about 30 A4 pages of additional, autonomous task-based ME writing. In terms of the language accuracy, individual feedback involved correction of recurrent language errors (e.g. vegitables in the post above) as well as challenging self-correction (the student was asked to correct the lack of agreement in his/her comment, e.g.: eat strawberry as it contains...).

\section{$B$-writing project outcomes}

Employment of task-based asynchronous blog-writing in ME contributed to significant improvement of the students' autonomous reception and production (McLoughlin 2008) (see Table 1 below):

Table 1. B-writing project - quantitative results

\begin{tabular}{|c|c|}
\hline Production & $\begin{array}{l}\text { - Over } 770 \text { comments by } 25 \text { students } \\
\text { - Teacher-to-student ( } \mathrm{T} \text { to } \mathrm{S} \text { ) and self-correction was } \\
\text { visible for all comments versus the private character of } \\
\text { feedback and correction in classical writing }\end{array}$ \\
\hline $\begin{array}{l}\text { Listening } \\
\text { (YouTube clips) }\end{array}$ & 5 additional video clips \\
\hline $\begin{array}{l}\text { Reading } \\
\text { (extra medical articles) }\end{array}$ & $\begin{array}{l}7 \text { articles on: } \\
\text { - Low-cost dental care } \\
\text { - Excess sugar linked with heart disease death } \\
\text { - The truth behind major dentist myths } \\
\text { - Association of parental stress and early childhood } \\
\text { caries } \\
\text { - Case study } \\
\text { - Free checks in Edinburgh to raise awareness of } \\
\text { mouth cancer } \\
\text { - Foods your dentists avoid; Teacher and peer } \\
\text { comments }\end{array}$ \\
\hline Vocabulary revision & Vocabulary quiz with PhotoPeach \\
\hline
\end{tabular}

Besides the communicative ME purpose, the B-writing project represented a faithful portfolio of student activities and was employed for evaluation and progress documentation, the feedback being individualized and transparent (Pop 2014).

The major B-writing project drawback was that it was time-consuming for both teacher and students: it was difficult for one teacher to offer quality feedback to such an extensive input as most comments clustered in the pre-examination period, which further demonstrates that students are extrinsically motivated to a great extent. 
As a final recommendation, peer comments rather than comments responding to the teacher's initial post should be encouraged as these would enhance communicative cross-exchanges and, therefore, collaboration.

\section{Conclusions}

The paper fills a gap in the literature on technology-task-based speaking and writing for pre-service Medical English and reflects on results and challenges of such class-size student-centred and learning-oriented customization.

Project outcomes and students' reflections on the tasks confirmed the adage that the less we teach, the more they learn:

- both asynchronous writing and speaking projects allowed students to revise, reflect, and therefore to learn;

- solving real tasks determined students to read more extensively in order to articulate original points of view;

- public writing allowed comparison with peers' productions and generated more faithful self-assessment in terms of content and accuracy proficiency;

- providing additional opportunities for writing practice made students more conscious that editing and constant improvement are mandatory;

- satisfaction and confidence in language use increased with practice;

- more students engaged in the speaking than in the writing project $(97.6 \%$ versus $40.3 \%$ ), which may reflect, on the one hand, the prevalence of preferred speaking versus writing learning style and, at the same time, on the latter's increased difficulty.

To conclude, as development of productive EMP skills are crucial within the context of career advancement and internalization of the medical labour market, technology may offer the right framework for the generation of additional relevant written and oral communication in order to bridge the gap between institutional learning and real-life communication.

\section{References}

Afton, Gillis-Katie, Luthin-Howard, P. Parette. 2012. Using VoiceThread to create meaningful receptive and expressive learning activities for young children. Early Childhood Education Journey 40 (4): 203-211.

Aponte, Judith. 2010. Using discussion boards, podcasting and VoiceThread in undergraduate nursing courses. In: G. Chova, D. M. Belenguer, I. C. Torres (eds), Proceedings of the Fourth International Technology, Education and Development Conference, Valencia, Spain: International Association of 
Technology, Education and Development, 3356-3358, retrieved from http:// library.iated.org/view/APONTE2010USI.

Bart, Mary. 2011. Pump up your online discussions with VoiceThread. Faculty Focus, retrieved from http://www.facultyfocus.com/articles/asynchronouslearning-and-trends/pump-up-your-online-discussions-with-voicethread/.

Brunvand, Stein-Byrd, Sara 2011. Using VoiceThread to promote learning engagement and success for all students. Teaching Exceptional Children, 43(4): 28-37, retrieved from http://www.voicethread.com/media/misc/support/ JTECVoiceThread.pdf.

Educause Learning Initiative. 2009. 7 things you should know about VoiceThread. Retrieved from http://net.educause.edu/ir/library/pdf/ELI7050.pdf.

Hirvela, Alan-Sweetland, Yuerong Liu. 2005. Two case studies of L2 writers' experiences across learning-directed portfolio contexts. Assessing Writing 10: 192-213.

Lerner, Janet, V.-Johns, Beverley, H. 2009. Learning disabilities and related mild disabilities (11 ${ }^{\text {th }}$ ed.). Belmont, CA: Wadsworth.

McFarland, Jonathan. 2009. Teaching English to the medical profession. Developing communication skills and bringing humanities to medicine. Panace X(30): 173-175.

McLoughlin, Catherine-Lee, Mark J. W. 2008. The three P's of pedagogy for the networked society: Personalization, participation, and productivity. International Journal of Teaching and Learning in Higher Education 20(1): 10-27, retrieved from http://www.isetl.org/ijtlhe/pdf/IJTLHE395.pdf.

Murray, Liam-Hourigan, Triona-Jeanneau, Catherine. 2007. Blog writing integration for academic language learning purposes: Towards an assessment framework. Ibérica 14: 9-32.

Pop, Anisoara-Dredetianu, Mirela. 2013. Assessment of speaking in English for Specific Purposes (ESP) Including a voice tool component. Studia Universitatis Petru Maior. Series Philologia. 15: 105-111.

Pop, Anisoara-Fenton, James. 2014. Offering individualized feedback in English for Medical Purposes through asynchronous writing. Proceedings of the $9^{\text {th }}$ International Conference on Virtual Learning (ICVL). Bucharest: Editura Universității din Bucureşti, 495-501.

Mitra, Sugata. 2011. Minimally invasive education - Hole in the Wall Project. Retrieved from: http://www.hole-in-the-wall.com/MIE.html.

Yang, Shih-Hsien. 2009. Using blogs to enhance critical reflection and community of practice. Educational Technology $\mathcal{E}$ Society 12(2): 11-21, retrieved from http://www.ifets.info/journals/12_2/2.pdf. 